\title{
System IT Supporting Communication in Formations of Security and Public Order - in Police
}

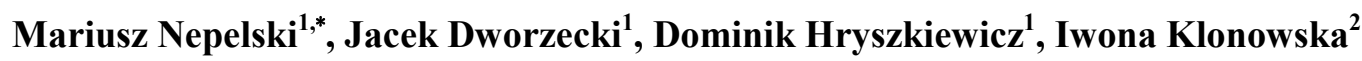 \\ ${ }^{1}$ Police Academy in Szczytno, Poland \\ ${ }^{2}$ Polish National Police, Poland
}

Copyright $(2017$ by authors, all rights reserved. Authors agree that this article remains permanently open access under the terms of the Creative Commons Attribution License 4.0 International License

\begin{abstract}
The purpose of this article is presentation of examinations results at creating the system supporting the officers' examination and the Police employees and other services responsible for internal safety of the State. System SINDBAD (Information System for Research and Decision Analysis) will be built basing on detailed analysis of future employees' needs and will be equipped with creating and examinations management modules, legal acts consultations, analysis of crisis situations and statistical analyses. The system will enable maximum anonymity of speech and securing against access of unauthorized people. The described examinations are conducted within the Project „, Construction of IT system supporting the Communications in the Police and in dependent forces MSW in aspect of internal safety, Nr DOB-BIO7/03/01/2015 co-financed by National Research and Development Centre in Warsaw. The result of the Project will be among others anonymous IT module platform serving as collection and analysis of data enabling monitoring of problematic areas and planning intervention on the level of organization in order to ensure internal security, including organizational-technical solutions ensuring anonymity of involved people. Therefore, the presentation of detailed analysis will be possible after completion of the project - at the beginning of the year of 2018. As of now, we can only show partial results and the comprehensive analysis will be available when the project is finished.
\end{abstract}

Keywords Management, Communication, Security, Information, Police

\section{Introduction}

The expectations concerning finding solutions improving efficiency of communications in formations subordinate or supervised by the minister for Interior (MSW) especially the Police, enforce undertaking interdisciplinary examinations.
That is why the scientific- industrial consortium whose leader is The Police Academy in Szczytno (Poland), received a grant for performing research "Construction of IT system supporting communication in Police and other services subordinate to MSW in security aspect", $\mathrm{Nr}$ DOB-BIO7/03/01/2015. The grant was received within the competition $7 / 2014$ for performing projects on scientific or research works concerning defence and security of the state. The Designed within the Project System is supposed to serve for examinations supervised by minister Interior.

The Project results will most take advantage of the most popular of formations, subject to minister of Interior and formed for protection of people and maintaining security and public order, which are the Police. Therefore further scientific exploration will refer to system implementation in this formation.

Project entitled "Construction of IT system supporting the Communications in the Police and in dependent forces MSW in aspect of internal safety", No. DOB-BIO7/03/01/2015 is co-financed by the National Centre for Research and Development in Warsaw, Poland. For the implementation of this project Police Academy in Szczytno, Poland, won the grant of 5 million PLN (over one million euro) and is obliged not to disclose the results of studies during the project implementation phase. Therefore, the presentation of detailed analysis will be possible after completion of the project - at the beginning of the year of 2018. As of now, we can only show partial results and the comprehensive analysis will be available when the project is finished.

\section{Range of Police Activities}

Police as a formation created for protection of security and public order performs entrusted tasks basing on the statutory law. The norms of conduct are determined by regulations especially ordered by the Police Commissioner but also by other superiors in personal cases. Mentioned regulations being the form of official orders, decisions and commands. 
Norms of procedure regulate the whole scope of activities of the Police and their updating is characterized by many factors among others by changes in legislative law. Changes of norms are by assumption striving for perfecting the Police activities, just like in the theory of quality management. In the Polish Police the model EFQM (European Foundation of Quality Management) is used and the implementation of the system of quality management was initiated in 1999 by the Police in Świętokrzyskie. The next was The Police Office in Elblag, which chose application for gaining certificate of accordance with ISO 9001 and winning it in the year 2001 . Next year certificate ISO 9001was obtained by Police College in Szczytno. Popularity of this norm caused in subsequent years almost massive race for gaining the mentioned certificate by a number of Police units in Poland. It should be noted that police units not possessing the ISO 9001 certificate are not worse at detecting criminals or crimes.

One of the elements of efficient continuity management in Poland is its structure.[1]. The rule is that at forming and restructuring of organization Police units, one should consider the requirements of efficiency of activities in performing statutory Police duties. Moreover it is indispensable to consider specialization, continuity and financial possibilities. The structure of time jobs is fixed with maintaining proportions between the numbers of police positions in particular unit and general number of Police positions in the voivodeship scale. For generals and senior officers and junior it is $20 \%$ for the inspectors, noncommissioned officers and privates it is $80 \%$. There was defined a Job time normative of Police units -ex: police station and specialist police station in Poland -15 , prevention unit 240, independent subunit of antiterrorist Police 44 . In The Police three kinds of service were introduced: preventive, criminal and supporting.

Introduced organization of service directed for continuity of activities and All difficulties in form even of extraordinary events, crisis cannot cause the break-up of organization and Only possible delay in performing of particular events. The supervision of continuity is controlled by the Commissioner. His duties include supervision over continuity of activities to which one can include initiating and coordinating activities of Police units in range of defined purposes as statutory Police duties.

Police Headquarters in the field of criminal service forms conditions for planning, ta king decisions and coordinating activities heading for efficient recognition and fighting criminality of domestic and international range. They take control of preventing and physical fighting of terrorism and organizing, coordination and supervision of the Police activities. Another task is conducting special operations and performing crown witness protection programme and for their families. Moreover they ensure organizational and technical possibilities of using operational technique and develop and promote new technical solutions in this field. The priority is implementation and monitoring and perfecting in the Police the criminal standards, recognition of criminal structures and methods which are used by specialized groups and coordination and monitoring of recruitment. Direct cooperation with foreign police formations or their international organizations, including Interpol and Europol and organs and institutions entitled to prevent and fight criminality.

The range of activities of The Police Headquarters includes also area of activities of prevention services, which is responsible for monitoring, analyzing and assessment of way of action of police performing prevention tasks, developing and implementation of new standards. Moreover, the priority tasks are organizing and coordination of activities in the range of criminal prevention, prevention of crimes and wrongdoing, juvenile crimes, phenomenon of pathology, cooperation with organs of legal protection, public administration organs and social organizations for fighting criminality. An important area is also planning, organizing and coordinating of Police units in conditions constitutionally defined as extraordinary states and in case of extraordinary risk for people and environment. Another equally important task is inspiration, organizing, coordination and supervising tasks connected with nationwide Police operations taken in order to ensure order and security during organized public and social protests connected with mass events.

The Police Headquarters also take a number of activities arising from supervision over entities having in the range of their activity security and public order, whose duties include supervision over specialist protective armed formations and possession of weapon and ammunition by people possessing permission for gun.

The range of Voivodeship Police Headquarters and District Police Headquarters are the consequences of tasks performer on the central managing level, being a part of organizational-tactic chain and have direct influence on management of continuity in the Police. They carry the burden of performing the tasks by the Police. There is the rule that voivodship Police Offices and Police Headquarters have advisory function. Executive function is only for complicated matters with so called "gravity".

The key priorities of Polish Police approved by the Commissioner for years 2016- 2018 are:

- Increasing the efficiency of Police activities by stronger cooperation with the society

- Raising efficiency of the Police activities in identity and lighting contemporary dangers, including cyber criminality.

- Increase of efficiency of Police activities in fighting the most socially tiring criminality

- Police activities oriented for improvement of security in the traffic.

- Optimizing Police activities in favour of ensuring security at mass cultural events.

- Raising the quality and work efficiency by successive rising of Professional skills of officers and Police employees. 
- Perfecting the quality of tasks performed by policemen and employees of the Police by ensuring optimal conditions of service/work

Knowing the range of Police activities as a hierarchy organization is a factor introducing in the topic of this research paper.

\section{Social Communication in the Police}

Trying to discuss "social communication" in the Police, it is necessary to start from explanation of idea communicating. Therefore, the idea comes from the Latin word communico or communicare, which means -to confer .In modern languages it appeared in XIV century and meant -'entering the community, maintaining relations with somebody'. Only in the XVI century as a result of post and road development it was given a second meaning-transmission. The double sense of communicating is still valid. In one situation communication is a synonym of public transport, in another transmission of information between people [2]. Further scientific thinking must consider internal communication which is perceived as a process of exchange of information between participants of organization system and associating its various parts. Efficient communication means that information within an organization reach the target without interruptions and according to the sender's intentions. The way of conveying information should enable the recipient full acceptance of the contents and using them in their everyday work. [3].

The research of internal communication neither is popular in worldwide nor in Polish subject literature. The problematic aspects of social communication in the Police have not been a subject of interdisciplinary studies within pragma linguistics. However internal communication as an autonomous phenomenon is present in very few research papers. Available scientific social communication publications dealing with rules of efficient Communications are books of theoretical, scientific or popular science character. They discuss the strategy of internal communication from managerial point of view, including management of personnel, marketing and public relations. The good image of the Police starts with everyday professional service of each policeman and depends on professional, communication and narrative skills. Almost each Police officer is present in two dimensions- internal and external and the quality of their functioning in each of them depends on constant improvement of internal Communication [4].

Narrative marketing is undoubtedly a new quality in the Police. Used in promotional communication and in business but has not been so far applied in external and internal Police communication .Police Officers apart from professional skills must possess excellent communication skills and according to prof. J. Stawnicka narrative skills as well.

Regarding so called professional communication in the Police, the subject literature considers deliberations concerning way of communications in special situations. Unfortunately, such research papers are still insufficient in Poland. One of special publication in this context is is research paper of Police Academy in Szczytno Social Communication in the Police[5], however it does not contain material examinations, but practical indications from general area of communication, and Police in Poland. The present situation and perspectives [6] and Internal Communication in the Police [7]. It should be underlined that articles dedicated to internal communication problems were regularly published in "Police 997" magazine. Here one should underline that meaning of research in pragma linguistic context embraces specification of language in meetings and briefings, quality of Communication subordinate-superior and internal Communications between employees. At the same time, efficient communication cannot be reached by management of the same information basing on reasonable conversation model by British philosopher Herbert Paul Grice. The model is a kind of cooperative discourse and is based on the following rules:

- Quantity ( convey as much information as is necessary for achieving the goal)

- Quality (in communications do not express which is groundless )

- Reference (passed on information must be appropriate to the Leeds and circumstances of communication)

- way (be understanding and tactful towards your partner and avoid ambiguity)

Internal communication research could define the degree of ritualization of superior -subordinate relationship in official and unofficial contacts in organization, the degree of innovativeness, degree of officialdom, degree of colloquialism and grounds of application of the above mentioned conversational statements. This context refers to grounds of maxim of quantity and reference from the discourse of communications undertaking point of view by Jurgens Habermas presented in Theory of communicative action [8].

The issues connected with the safety inside the organization and communication is difficult to examine in classical methodology. The participants not having the guarantee of anonymity may not reveal their true ideas and not report important problems. The proposed IT system is supposed in serve in executing significant examinations within the organization, identification and monitoring of threats (which may be hidden in traditional systems of reporting), and consulting of legal acts from the point of view of officers carrying duty on various levels. It is supposed to back up free expression of opinions.

\section{Description of the Project-Results of the Examinations}

The main purpose is creating system supporting examination in population of officers and Police employees 
in order to monitor and predict threats, improve the Communications efficiency, prediction of threats, consulting and analysis of crisis situation in area of Essentials matters for the subordinate formations or supervised by the Minister of Interior, responsible for internal security. The System must be equipped with diagnostic and analytical tools enabling designing, collecting data and analysis of results. The purposes have been defined as follows:

- Working out technical-subject assumptions, defining critical functions of system so ensuring efficient methods of obtaining data for ensuring internal security by streamlining Communication In the Police and other services subordinate to MSW.

- Specification of areas of diagnosis of threatening factors and their conditioning, monitoring and minimizing, working out crisis analysis to review research inside the organization, risk factors, consulting legal acts and correct Communication inside the Police.

- Working out module tools for conducting legal acts consulting and reporting innovative solutions.

- Working out algorithms of data analysis by diagnostic tools, supporting solving problems from the area of risk management, internal Communications, crisis situation analysis and prediction of threats in the Police.

- Working out a set of training scenarios to be used basing on real action of services subordinate to MSW is assessed as controversial ones. Basing on data from the system it will be possible to collect data, form guidelines, integration of information between the services, elimination of language errorsmisunderstandings ex; during instructions, arising from ex. character of service. Working out scenarios will show possibilities of system for analyzing so called difficult situations.

- Implementation and verification of worked out tools. The diagnostic tools should be implemented in the form of application- net platform, working in safe internet connection. The platform should ensure users comfortable and anonymous logging and free expressing of opinions. The analytical tools should be implemented in form of software cooperating with platform of diagnostic tools. They will serve for optimizing the efficiency of flow of information and taking decisions in above described areas. Ultimately one should create tool of optimization of flow of information process in performing service duties in the Police.

- Optimizing the diagnostic and analytical tools, finished by demonstrating of full functionality and performing project assumptions in real conditions (net implementation). Working out detailed recommendation of increasing communication efficiency with the use of planned system. Full readiness for installation in safe internet connection must be shown.

The IT communication back-up system in Police and other formations subordinate or supervised by minister of Interior in aspect of internal safety will be an innovative solution on the scale of the country. At present, there is no similar system functioning in any formation superior or supervised by MSW. The essence of the built solution is its creation to serve well and come up to the expectations and possibilities of particular formations. Especially expectations are high, which is why during its building it will be necessary to use innovative solutions in the area of IT. Executing of the project will considerably influence the efficiency process of internal communication. The solution will serve for executing of essential matters within the organization, identification and monitoring of threats (which may be hidden in traditional systems of reporting) and consulting legal acts project from the point of view of officers performing duties on different levels. It is also supposed to support free expressing of opinions about cooperation of different services. Solutions improving efficiency of communication will be implemented. The system will contain ready diagnostics tools for conducting examinations, monitoring threats, consulting and crisis situation analysis. The system will have an open character and possibility to add new measuring tools in the future if there is such a need. Diagnostic tools will enable anonymous logging so they will possess individual logins for users. Analytical module will account for software executing functions of data processing in order to improve the decision ma king process in the office hierarchy, both in crisis and in routine situations.

The Project realization will considerably influence security of the State by increasing work efficiency of the Polish Police. The undertaking promotes use of modern tools in internal communication in favour of use of modern technology. The new system will improve efficiency of monitoring of expectations and social needs in area of safety. This will allow better selection of methods and forms of work of the Police, both in local communities and in professional groups. Created IT solutions will be environment friendly and providing possibilities of full electronic document treatment which is the base of information management. Necessity of ensuring the security of data will be fulfilled with the respect of natural environment thanks to use of database solutions supporting automatic security copy creating or replication. Working out modern methods of effective internal Communications for the Police and other MSW formations may help in rationalization according to human resources management rules which means more efficient use of organizational resources and according to demands of balanced social-economic development. In practice it means more efficient planning of human resources and estate of the Police, including first of all internal training systems and professional improvement and employees skills management. New distinct areas of organizational activities of the Police, may also determine the necessity of creating new places of work and improvement of quality of work in the Police. Additionally rationalized Communications efficiency system will influence the improvement of quality of the policemen work civilian employees' as well. The new 
information management system will improve the exchange of knowledge and experiences both within the police and within other services and institutions. It will enrich the pragmatics of pursuing and detecting crimes and wrongdoing. There should be worked out and implemented information action spreading in officers knowledge about the project, its safety and possibility to use.

Within the Project, there will be a tool worked out on IX level of technological readiness for implementation in practice in any time. However, its deliberate implementation seems as fast as possible due to the needs of Communications internal efficiency within the internal services of MSW. The system will develop dynamically also after the end of the Project according to finished product recipients' needs by updating the module. It should be noted that component techniques used for implementing the neuralgic modules will enable easy adaptation and exchange of their functionality (e.g.: creating new more effective version of the same module). Module components of Interand external sources will be designed to enable continuous system development regardless of changes in the structure and contents of processed previously sources. It will be possible to add new, so far unknown sources and considering selected information provided by them in the area of meta data. To sum up, using the components will ensure continuous development of the system and will enable easy updating; thanks to it the process of "aging" in technology will be considerably limited.

The system will contain ready diagnostics to for conducting examinations, monitoring the threats, consulting and analysis of crisis situations. Moreover, the system should have open character and enable adding new measuring tools depending on needs in the future. As an assumption, in the described system there will be no possibility to express on personal topics. Diagnostic tools should enable anonymous logging so there should be individual logins for officers and employees of subordinate or supervised formations by minister of Interior and defined method of their distribution. The system will be provided with a series of cooperative modules the module of crisis situation analysis will serve in gaining information from many formations enabling analysis and improvement of algorithms of synergy in order to ensure internal security. The analytical module should account for software performing functions of data processing in order to back up the decision ma king process connected with forming and improving the flow of information in Professional hierarchy both in crisis and routine situations. There will be ready training scenarios based on activities of formations subordinate or supervised by the minister of Interior, assessed as controversial or difficult. Basing on data from the system it will be possible to collect data, form guidelines and integrate information between the formations. Defined scenarios demonstrate possibilities of system for analysis of difficult situations.

The documentation of system will consist of technical and subject part. The technical part should describe way of construction, installation and use of system. Especially, there should be designer and implemented the way of entering data, whose part will be an instruction for users (examined people) presenting the system assumptions. The subject part should be a theoretical description of basic construction of implemented measuring tools (including scientific data obtained during the process)

Definition of version based on independently safe net connections and definition of final version of the system location will be taken by the end user (required compatibility with standard PSTD required -Police Net of Data Transmission). The Police should have a possibility of implementing the system both in internal net (PSTD) and in external safe internet connection. The other users should have possibility of using the system in safe connection to which the access will be limited. The system should ensure the possibility of integrating data and reports from all the users.

The users of the system will be:

- The structures of interested formations subordinate or supervised by the minister of the interior, whose scope of activities requires decisions based on examinations of the officers and employees and working out and implementing the strategic decisions.

- The scientific units performing examinations in favour of services subordinate to MSW.

The system implementation may be potentially interesting for all organizations responsible for security in the state, for which collection of honest and credible answers of the members is indispensable. The possibilities of anonymous threat reporting may be also useful for airlines, railway and large industrial companies. Potentially, it is possible to use the system according to the project in the state services and there is also a possibility of its commercializing in the future.

\section{REFERENCES}

[1] Zarządzenie nr 1041 Komendanta Głównego Policji z dnia 28 września 2007 r. w sprawie szczegółowych zasad organizacji i zakresu działania komend, komisariatów i innych jednostek organizacyjnych Policji, Dz.Urz.KGP.2013.50.

[2] Dobek-Ostrowska B., Komunikowanie polityczne i publiczne, Warszawa 2016.

[3] Trzcińska W., Wiciak I., Skuteczne komunikowanie w administracji publicznej, Szczytno 2011.

[4] Projekt naukowo-badawczy „Strategia komunikacji wewnętrznej w Policji”, autorstwa prof. dr hab. Jadwigi Stawnickiej z Uniwersytetu Śląskiego, Polska.

[5] Cichorz T., Misiuk A., Wiciak I., Komunikacja społeczna w Policji, WSPol Szczytno 2006.

[6] Szymaniak A., Ciepiela W. (red.), Policja w Polsce. Stan obecny i perspektywy, Poznań, 2007.

[7] Hermanowski M., Weremiuk S. (red.), Komunikacja wewnętrzna w Policji, Poznań 2011. 
[8] Habermas J, Teoria działania komunikacyjnego. T. 1. Racjonalność działania a racjonalność społeczna, Warszawa 1999.

[9] Black S., Public relations, Kraków 2003.
[10] Gregory A., Public relations w praktyce, Kraków 1997.

[11] Projekt rozwojowy pt. „Budowa systemu informatycznego wspierającego komunikację w Policji i innych służbach podległych MSW W aspekcie bezpieczeństwa wewnętrznego", Nr DOB-BIO7/03/01/2015.. 